\title{
Schiller e a intersubjetividade teatral
}

Charlotte Morel - ENS/Lyon

Tradução de Pedro A. da Costa Franceschini

A leitura aqui proposta se concentra nos textos que Schiller consagra ao trágico, a saber, os dois ensaios de 1791, Sobre o fundamento do prazer com os objetos trágicos e Sobre a arte trágica ${ }^{1}$. Além deles, utilizo também um texto mais tardio, todavia essencial, de 1803, que constitui o prefácio de uma de suas últimas peças, a Noiva de Messina, intitulado Sobre o uso do coro na tragédia (NA, X, p. 7-15). Acrescentando-se a esses textos estéticos dois exemplos dramáticos da produção schilleriana, será possível ver como uma interrogação do filósofo ressoa nas discussões em torno da questão da cena. Uma observação. Nos textos com os quais devemos nos confrontar, escolhi destacar o que neles não depende de Kant, tendo em vista que o que os filósofos conhecem a respeito de Schiller geralmente se restringe àquilo que, nos textos estéticos, tem ligação com o pensamento

${ }^{1}$ Schillers Werke. National-Ausgabe [Aqui citado como NA acompanhado do volume e páginas correspondentes], Bd XX (Philosophische Schriften erster Teil), respectivamente p. 133-147, 148-170. 
kantiano. É verdade que Kant e sua teoria do sublime estão no centro da proposta dos textos de 1791, como também no texto de 1793 sobre o patético. Mas é bom não esquecer, para os primeiros, da importância de Lessing; e, para este último, além de Lessing, da importância de Fichte ${ }^{2}$.

\section{A tragédia como modelo da situação intersubjetiva da "emoção"}

\subsection{De Lessing a Schiller: como a tragédia se torna o modelo da situação intersubjetiva da "emoção".}

Tratar da "emoção" depende ao mesmo tempo de uma análise das estruturas que a empregam dramaticamente, de uma análise filosófica de sua estrutura como modalidade específica do afeto e, por fim, de sua função sobre um duplo plano, estético e moral. Quanto a isso, a "compaixão" ou "simpatia" (Mitleid: voltaremos à ambiguidade), o "amor", são estruturas intersubjetivas sobre as quais uma teoria do sujeito também pode se debruçar. Por outro lado, a especificidade do dispositivo teatral, na tríade de seus elementos constitutivos: autor-atores-público ${ }^{3}$, parece

\footnotetext{
${ }^{2}$ Quando pronunciei esta conferência em Paris, Danièle Cohn chamou minha atenção para o capítulo "Un oubli de Kant", que acabava de ser publicado em sua obra L'Artiste, le vrai, le juste (Paris : Éditions rue d'Ulm/Musée du quai Branly, 2014, pp. 37-54). Com efeito, é interessante cruzarmos nossas perspectivas, uma vez que ambas buscam sublinhar as diferenças estéticas, as quais procedem de uma diferença no que viria a ser o afeto em Schiller e em Kant. Em nossos dois textos, a dimensão da compaixão é enfatizada como componente fundamental da divergência, tendo aí também Lessing como terceira referência comum.

${ }^{3}$ Os quais Schiller comenta como tais desde 1782: cf. Sobre o teatro contemporâneo, NA, XX, p. 79-86.
} 
feita para alimentar uma reflexão estrutural sobre o posicionamento respectivo dos sujeitos; personagens e espectadores, de um lado e de outro da cena, parecem evidentemente clivados pelo próprio dispositivo cênico: mas será que isso significa que eles são clivados na qualidade de sujeitos agentes ou não, sujeitos que colocam em ação respectivamente sua faculdade de atividade de um lado, de receptividade de outro? São termos centrais para toda análise estética geral de Schiller; mas, entre os dois lados, o que se desenvolve é antes uma dialética - de maneira que o teatro é também mobilizado para permitir uma relação com muito mais nuances do que essa oposição radical entre um polo e outro. Algo que mostra isso direitamente, como um fato, é a categoria afetiva e estética de participação; isto é, a "parte" afetiva que prende o "espectador" à situação do "ator". A emoção é essa participação, quando ela se entrega pelo menos "ao espetáculo de alguma coisa".

Na Correspondência estética sobre o trágico, Friedrich Nicolai lança a fórmula segundo a qual "o fim da tragédia é excitar as paixões" (der Zweck des Trauesrspiels ... Erregung der Leidenschaften); em sua resposta, Lessing não se opõe a isso, reordenando, no entanto, as duas máximas que Nicolai colocava em oposição na relação que une o fim e os meios: "a tragédia deve excitar as paixões" a fim de que "a tragédia nos torne melhores"( Lessing a Nicolai, novembro de 1756). O que me interessa aqui não é mais esse debate em si mesmo, mas a substituição que encontramos em Schiller: no ensaio Sobre a arte trágica, de 1791, o que se tornou "o fim da tragédia" é agora a "emoção" (Rührung) (NA, XX, p. 169). Além disso, em relação a Nicolai, a questão consistia para Lessing em indicar qual "paixão" (ou quais paixões) a tragédia "excita" (Lessing a Nicolai, novembro 
de 1756). Sua conclusão: "não penso que a tragédia desperte no espectador outra paixão além da compaixão" (Mitleid) (Ibid.). Trata-se aí da tese própria de Lessing; ao contrário Mendelssohn e Nicolai, eles não admitem limitar a ação da tragédia a engendrar a "compaixão", e pretendem estendê-la a "todas as paixões" (Mendelssohn e Nicolai a Lessing, janeiro de 1757).

Se voltarmos a Schiller, veremos que está de acordo com Lessing quanto a isso: "uma arte que se dá especificamente por fim o prazer da compaixão se chama arte trágica em sentido geral" (NA, XX, p. 153). Se nos debruçarmos aqui sobre o detalhe do texto schilleriano, toda uma rede de substituição de uma frase e uma fórmula por outra permite mostrar que a "compaixão" é reconduzida à emoção, como esta última substitui a paixão ${ }^{4}$. Essa "identificação", aliás, decorre logicamente da definição que Schiller oferece da emoção, em seus textos de 1791 consagrados ao trágico - "a emoção, em sua significação mais estrita, designa

\footnotetext{
${ }^{4} \mathrm{Cf}$. o fim do ensaio: os cinco pontos sucessivos por meio dos quais Schiller constrói sua definição final da tragédia são destinados a reencontrar a tese do fim trágico situado na compaixão: "a tragédia reúne todas essas qualidades a fim de excitar o afeto compassivo" (den mitleidigen Affekt zu erregen). No interior dos cinco pontos sucessivos, o quarto indica que "a tragédia é [...] a imitação poética de uma ação digna de compaixão" (o que a coloca em oposição à imitação histórica). Schiller procede aqui por adjunção, após ter proposto nos três primeiros pontos que ela é da instância 1) da imitação, 2) de uma ação, 3) de uma ação completa (unidade da ação). O quinto ponto determina, além disso, de que se trata por fim na compaixão, fazendo da tragédia "a imitação de uma ação que nos mostra, a nós seres humanos, no estado de sofrimento": pois "só o sofrimento do ser sensivelmente moral, tal como somos, pode despertar a compaixão". (NA XX, p. 167). No momento final do texto, a definição da tragédia, dada dessa vez através de seu fim e de sua forma, situa esta última como "a imitação de uma ação comovente" ou ainda "que conduz ao sofrimento", sendo o próprio fim reformulado como o fato "de excitar o afeto compassivo" (NA, XX, p. 169).
} 
a sensação mista de sofrimento e prazer, sentida no sofrimento" (NA, XX, p. 138). Referindo-se diretamente ao problema geral do prazer estético experimentado nos afetos desagradáveis, essa definição inclui, a determinação do termo Mitleid, tomado como "sentimento misto", assim como Mendelssohn o fizera (e, de fato, imediatamente depois, Schiller evoca o "prazer que um espectador compassivo sente"). Mas então põe-se a pergunta: não é possível comover-se com outra coisa que não o sofrimento? É o que se vê, justamente, nos exemplos dramáticos schillerianos que citaremos mais à frente.

Mas, então, por que a substituição de "paixão" por "emoção"? No texto da Arte trágica, Schiller enuncia não somente a definição de emoção, mas descreve o que lhe parece ser sua estrutura própria:

A todo momento, a [faculdade autônoma] deve estar ocupada em manter sua liberdade, contra o constrangimento da sensibilidade; mas não deve alcançar a vitória antes do fim e, menos ainda, sucumbir ao combate. Caso contrário, acaba-se com o sofrimento, no primeiro caso, e com a atividade, no segundo. Ora, apenas a reunião de ambos excita a emoção. É justamente na hábil condução desse embate que reside o grande mistério da arte trágica. (NA, XX, p. 163-164)

Nessa análise da emoção como efeito do jogo estrutural da atividade e da receptividade, encontra-se, a meu ver, uma tese forte de Schiller. Da "paixão" à "emoção", seríamos tentados a comentar imediatamente que se dá uma passagem da mera receptividade passiva a essa estrutura mista que reúne dois opostos. 
Mas não se trataria aí de algo mais complexo? Também quanto a isso, Schiller poderia se recordar do Lessing da correspondência estética. Este, para elevar-se às causas capazes de ligar a "paixão" a um prazer, tanto no caso dos afetos agradáveis como no caso dos desagradáveis, recorria a uma linha de análise emprestada da psicologia procedente de Leibniz e de Baumgarten: ao referir "paixão" à noção mais primitiva de "afeto", seria possível, ao mesmo tempo, sublinhar nesta última uma determinação que remete tanto à atividade quanto à receptividade. Uma vez que o afeto é "consciente", ele nos reconduz a "uma maior determinação de nossa força" (Lessing a Mendelssohn, 2 de fevereiro de 1757).

Remeter a essa análise de Lessing certamente não nos oferece ainda a razão da escolha de Schiller por "emoção" em lugar de "paixão", mas dá testemunho de uma posição mais próxima à de Schiller do que à de Kant, no que se refere à estrutura afetiva do sujeito. Quando, no texto de 1791, essa estrutura é pensada como "reunião" de atividade e passividade, ela desponta como a reconstrução, em termos kantianos, de uma posição que, a meu ver, no fundo não é kantiana, mas apenas integra a oposição kantiana como um momento constitutivo de sua dinâmica própria $^{5}$.

A emoção acaba por se caracterizar como a posição psíquica em que o espírito toca ao mesmo tempo a "raiz comum" da atividade e da passividade subjetiva, sem com isso deixar de apontar, para o sujeito, o inelutável movimento de sua dissociação. Encontra-se aí outra ideia de Schiller muito marcada pela descoberta de Kant (uma vez que no sistema da "perfeição" está

${ }^{5}$ Uma passagem que recortará, nesse sentido, a própria oposição dos dois paradigmas do ingênuo e do sentimental no ensaio de estética de 1795 . 
implicada a ideia de uma finalidade sempre visada como "preenchida" - qualquer que seja o "grau" no qual ela o esteja). É o que se percebe quando ele sublinha, na operação própria ao regime da emoção, uma "inadequação" relativa às finalidades do espírito. Na sequência a uma página bem kantiana do ensaio Sobre o prazer nos objetos trágicos, é assim que ele apreende, com efeito, a continuidade entre comovente e sublime (uma continuidade ainda posta no ensaio de 1793, Sobre o sublime, do qual o ensaio Sobre o patético é originalmente a segunda parte), indicando então que "o comovente e o sublime têm em comum o fato de (...) darem a sentir (...) uma finalidade que supõe uma inadequação a um fim" (NA, XX, p. 137). Sabe-se como se dá essa questão em Kant, na Analítica do Sublime, e é precisamente esse movimento que Schiller retoma de modo explícito ${ }^{6}$. Contudo, aplicar esse esquema ao "comovente" e não mais somente ao sublime, é uma iniciativa própria de Schiller; e o ensaio Sobre a arte trágica, que segue à primeira publicação Sobre o prazer com os objetos trágicos, vai justamente também oferecer a essa categoria do comovente um prolongamento rumo à noção mais explicitamente intersubjetiva de compaixão. Isso permite voltar à ambiguidade ainda presente entre os dois termos: para que emoção comece a abranger compaixão, de modo a substituí-la no enunciado da teoria do trágico procedente de Lessing e de Aristóteles, não será necessário que Schiller se encarregue precisamente de ampliar o próprio alcance da compaixão? Mendels-

\footnotetext{
6 "O objeto do sublime contraria (...) nossa faculdade sensível, e essa inadequação a um fim deve necessariamente despertar em nós o desprazer [;] mas ela se torna ao mesmo tempo uma ocasião de nos fazer conscientes de outra faculdade em nós, superior àquilo que subjuga a imaginação [;] um objeto sublime, precisamente porque ele contraria a sensibilidade, é portanto conforme ao fim da razão..." (NA, XX, p. 137-138).
} 
sohn, na correspondência de 1756-1757, a definira classicamente como "a consideração intuitiva da infelicidade de um outro" (Nicolai a Lessing, 14 de maio de 1757), mas Schiller insistirá igualmente sobre a "compaixão por si mesmo", e isso poderia muito bem assinalar nesse caso o retorno reflexivo que deveria por fim caracterizar toda "emoção" em sua estrutura própria. Trata-se então de considerar como esta funciona com o que poderíamos chamar uma "caixa de ressonância intersubjetiva".

\subsection{A emoção como "caixa de ressonância" subjetiva}

Paralelemente ao fato de colocar de maneira explícita a emoção como uma estrutura de união da atividade e da passividade, Schiller acabava por determiná-la através de um vaivém entre as condições subjetivas da relação a si e da relação ao outro. É a esse respeito que o dispositivo cênico, conjugado à escritura dramática, aparecerá como particularmente apto a experimentar não-especulativamente o que sucede a essa "especularidade" subjetiva.

Relendo algumas peças de Schiller, pareceu-me que uma das maneiras de mostrá-lo poderia ser dando atenção àquela que, em sua obra, poderia ser elencada no gênero inédito da "tragédia comovente": Don Carlos, de 1782. (Para esse gênero inexistente, seria necessário forjar em alemão o termo "rührendes Trauerspiel", sabendo que os gêneros elencados, tendo surgidos notadamente sob a influência de Diderot e Lessing, são por um lado a "comédia comovente" - rührende Komödie - e, por outro, a "tragédia burguesa", bürgerliches Trauerspiel).

Don Carlos tem, no entanto, um estatuto peculiar na história das produções dramáticas de Schiller, devido a uma maturação 
muito longa, uma redação em várias fases, com numerosas transformações: parida "nas dores" de 1782 a 1787, com três projetos e quatro versões sucessivas, em prosa, em versos iâmbicos, para a publicação e "para a cena", retomada enfim só tardiamente em 1802. Deve-se assinalar que Schiller, durante todo o primeiro período de seu projeto, mantém manifestamente com seu personagem uma relação de uma natureza e de uma força surpreendentes:

Preciso lhe confessar: em certa medida, ele me faz as vezes de bem amada. Eu o carrego em meu peito, eu erro como ele por toda a região (...) Don Carlos tem, se me é permitido usar desse critério, a alma do Hamlet shakesperiano, o sangue e os nervos de Leisewitz e o meu pulso" (Schiller a Reinwald, 14 de abril de 1783, in Schiller, 1978, p. VII) ${ }^{7}$.

Na mesma carta, ele também havia escrito num elã de generalização: "todo poema, a meu ver, nada mais é que uma amizade entusiástica ou um amor platônico por uma criação de nosso cérebro" (Ibid.). As doze Cartas sobre Don Carlos testemunham, aliás, que em 1788 ainda Schiller não pode se separar facilmente dessa criação. ${ }^{8}$

${ }^{7} \mathrm{Na}$ mesma carta, Schiller faz o elogio de Leisewitz contra Lessing sobre o ponto preciso em que "este era o vigia de seus heróis, Leisewitz, o amigo deles". E logo antes de nossa citação: "o poeta deve ser menos o pintor de seus heróis que a sua bem amada, o seu amigo de coração". (Ibid.)

8 Cartas sobre Don Carlos, publicação no Teuscher Merkur (julho: 1-4, dezembro: 5-12) em seguida à resenha do Allgemeine Literaturzeitung (10-11 de junho de 1788). 
Por outro lado, Schiller não se limita à celebração da transferência idealizada de uma subjetividade em outra, seja ela, como aqui, uma subjetividade poética, fictícia e idealizada: "amor" ou "identificação" por seu próprio personagem, a aparente "extensão do eu" que ele conhece como autor, ele a transpõe também a seus próprios personagens, no interior da peça. Com efeito, o "casal" mais marcante da intriga sem dúvida não é tanto o infante Carlos e a rainha, amantes infelizes, mas o casal de amigos, Carlos e o marquês Rodrigo de Posa; a cena dois no primeiro ato é, a esse respeito, a apresentação da relação quase explicitamente passional da amizade-espelho de Carlos pelo jovem nobre, encarnação verdadeira (com a rainha) da virtude ideal no seio da peça; e então, de repente, se mesclam dois termos que travam uma relação intersubjetiva de "participação, assim como se mesclam dois "dramas" na mesma peça: em primeiro lugar, a "simpatia" de duas almas "harmonizadas" como duas liras de "mesmas cordas" (a metáfora reaparece várias vezes na peça), num "drama da amizade" ; em segundo lugar a "compaixão" sentida na exposição do caráter "trágico" do amor proibido" ${ }^{10}$ e, em terceiro lugar, o que constitui a verdadeira virtude dos personagens, é manifestamente a capacidade para a participação simpática com "a humanidade", tomada tanto em seu conjunto como em todos

\footnotetext{
${ }^{9}$ Dado o desfecho da peça: o ideal da amizade pode resistir aos assaltos do real? Sim, mas ao preço da morte de Posa. A metáfora da lira, dos instrumentos "harmonizados" entre si, reaparece várias vezes; ela é particularmente apoiada nessa cena ("... se você foi eleito, entre milhões de seres, para compreender-me, se é verdade que a Natureza, em sua criação, reproduziu Rodrigo em Don Carlos e que na manhã de nossa vida, ela proveu as liras de nossas almas com as mesmas cordas...") (Dom Carlos, I, $2)$.

${ }^{10}$ Resumido pela princesa Eboli, II, 9: "Er liebt, was er nicht sollte" ("Ele ama o que não devia").
} 
seus representantes particulares, a partir do momento em que o protagonista virtuoso alcança justamente a elevação necessária de visão para ligar o particular ao ideal (evidentemente, tocamos aqui no terceiro "drama", o drama político da luta de seus heróis "progressistas" contra o absolutismo, sua brutalidade e seu caráter dogmático, encarnados por Felipe II).

O ideal da participação simpática da amizade é estendido às dimensões da humanidade, sendo "o amor pelo gênero humano" a condição dessa participação. Mas, inversamente, o que define o "humano"? Uma passagem muito reveladora da grande cena dez do terceiro ato permite a Posa de enunciá-lo ao próprio Felipe: "Você mesmo permaneceu um homem (...), você continuou a sofrer, desejar como mortal; você precisa de simpatia (Mitgefühl). ${ }^{11}$ Se "a ideia do humano" é assim o que Schiller quer colocar em relevo na dimensão mais ampla de seu drama, essa ideia retorna ao mesmo tempo na estrutura de "participação intersubjetiva" do Mitgefühl que já ocorre no nível privado do drama intimista.

Mas, sobretudo, a função do Mitgefühl, que engloba o Mitleid, parece ser aquela sobre a qual levantei anteriormente a hipótese sobre a conjunção da "emoção" e da "compaixão" na própria teoria do trágico: a participação "simpática" da amizade atua como extensão intersubjetiva do eu, e essa extensão recorta o próprio "sistema" da emoção. Em todos os níveis da peça, a dramaturgia multiplica as indicações de inserção de um "circuito" no qual a participação simpática da amizade e os testemunhos de compaixão de um personagem pelo outro são constantemente

${ }^{11}$ Cf. D. Cohn, «Un oubli de Kant », pp. 48-49, pp. 53-54: "o humano de Schiller (pensado a partir da dor) não é o de Kant (pensado como faculdade moral do respeito pela lei): assim, o 'Teilnehmungsgefühl', a simpatia kantiana não estão ligados à dor." 
a alavanca da emoção que sobrevém à cena: assim, para tomar apenas alguns exemplos, Schiller faz Posa ficar "mudo de emoção" (in sprachloser Rührung) (Don Carlos, I, 1) após a tirada na qual Carlos invoca nele a única pessoa que lhe permite finalmente cair em "lágrimas" (Ibid, I, 2), (e por isto, voltar a ser em um sentido ele mesmo - "meu coração se cura nesse abraço" - redescobrindo uma participação em seus próprios sentimentos graças ao acordo ressonante sobre " a lira delicada de [suas] almas" (Ibid., I, 3). Aqui, então, a emoção (Ibid., I, 2) é explicitamente sublinhada (pelo jogo didascálico) como concomitante - acentuando ao mesmo tempo, na minha opinião, um traço particular no seio das estruturas de participação intersubjetivas. Entre compaixão e emoção, o fato de insistir no segundo termo evidencia precisamente que o "afeto comunicado" (termo de Schiller no ensaio Sobre a arte trágica de 1791) dá lugar a um afeto que se torna próprio do sujeito. Com efeito, inversamente, "compadecer-(se)" não vai sempre de par com a emoção nesse sentido preciso: o eco do "afeto comunicado" pode nos alcançar segundo outro esquema, quer dizer enfraquecido por sua própria comunicação, sem se projetar, pelo contrário, na "caixa de ressonância" da emoção. Ser "tocado" (gerührt de acordo com a tradução literal) compreende-se agora em dois sentidos, dos quais apenas um é "próprio". Assim, na Correspondência estética, Lessing recorria precisamente à metáfora das "cordas vibrantes" para insistir sobre os limites de um tal modelo de "participação" por meio do simples "eco" de um "mesmo" afeto; em um instrumento de cordas, se uma corda é tocada (quer dizer, no nosso contexto: o afeto originário do personagem que sofre), as cordas próximas vibram por "simpatia" (tal é ao menos o vocábulo mantido no registro musical, que distingue as 
"cordas simpáticas" das "cordas vibrantes"), quer dizer, elas vibram precisamente sem ser tocadas (no sentido físico: "cordas vibrantes", "que vibram"). Pode o espectador ou testemunha do personagem "digno de compaixão" contentar-se em "vibrar" assim por simples "eco" (desta vez: o afeto "comunicado")? Para Lessing, a compaixão devia, pelo contrário, conceber-se como um afeto próprio ao espectador, portanto de natureza distinta do afeto originário do personagem que sofre; assim, o afeto do espectador ou da testemunha é tão originário quanto o do personagem que sofre, e não simplesmente um afeto "comunicado": nesse caso, somos "tocados" como o seria uma segunda corda que o musicista (então para nós, o dramaturgo) "tocaria" depois da primeira. (Lessing a Mendelsohn, 2 de fevereiro de 1757).

Em Don Carlos, "emoção" e "participação" constituiriam um sistema, segundo essa articulação precisa. Mais uma vez, pareceme que haveria muitos exemplos dessa estrutura precisa como elemento marcante na peça de Don Carlos, a indicação expressa de emoção (Rührung, Bewegung, Ergriffen/heit]) aparencendo logo a seguir da indicação expressa de "participação" ( Teilnahme, Anteil) ou de compaixão (Mitleid, O processo da emoção diverge do efeito "simpático" analisado acima como "eco": se há um efeito de ressonância, não se trata daquele do eco, sempre enfraquecido por sua relação à fonte, mas aquele da "caixa de ressonância". Assim, o efeito emotivo cresce e não decresce por meio do jogo de reenvio de uma subjetividade à outra. O circuito intersubjetivo do afeto é então destinado explicitamente a se fazer sistema de amplificação afetiva. 


\subsection{Kant ou Lessing? Teor e fundamento morais}

O exemplo do Don Carlos, todavia, deve nos trazer de volta aos textos estéticos dos quais havíamos partido, retomando notadamente a questão da dupla herança que aparece ali: Kant e (ou?) Lessing. Nos dois textos de 1791, a virtude e o "sentido moral" são permanentemente referidos, em termos kantianos, ao sentimento da "liberdade", à faculdade de "autonomia", como "atividade", nesse caso, colocada em oposição à "passividade" da sensibilidade $^{12}$. No que concerne ao teor moral, poderíamos ter a impressão de nos encontrar doravante muito longe daquilo que era empregado no Don Carlos. O que encontramos no Don Carlos manifestava o acordo de Schiller com a posição lessingiana: o teor moral, do qual a tragédia pretende se fazer o "arauto", não consistiria em nada além da própria disposição à compai$x \tilde{a} o$, à participação plena e inteira nos sofrimentos do próximo, estendido aos próprios limites da humanidade. O drama schilleriano concebido como "rührendes Trauerspiel" não corresponde, portanto, à teoria da tragédia que Schiller reconstruía a partir de Kant. E no próprio texto de 1791, elementos morais na realidade mais próximos do sistema moral subjacente a esse tipo de drama são ao mesmo tempo sensíveis.

Qual é, efetivamente, a natureza particular do sentimento moral que poderia se considerar como originário? Notemos que a dimensão do afeto é ela mesma fundamental em Schiller. No próprio seio da tensão receptividade/espontaneidade, passividade/atividade, afeto/liberdade, trata-se de uma dialética originária, não de uma divisão, que o "prazer da compaixão" colocará então em evidência ao seu próprio nível. De fato, Schiller evoca

${ }^{12}$ Ver, por ex., Sobre a arte trágica, NA XX, p. 158-159, 163. 
um prazer propriamente moral ${ }^{13}$. Entretanto, e isso mesmo no momento em que o texto se apoia explicitamente sobre a teoria kantiana do sublime, a raiz do sentimento moral em questão não se identifica primitivamente com o que é para Kant o sentimento moral originário - qual seja o "respeito", o qual remete com efeito à "autonomia" e à "liberdade" do homem diante de sua parte sensível. Certamente, Schiller também recorrerá a esse segundo sentimento na sequência de seu ensaio ${ }^{14}$, mas é $\mathrm{em}$ primeiro lugar o "prazer da compaixão" que ele analisa como prazer propriamente moral ${ }^{15}$.

A estratégia de Schiller, na sequência do ensaio, é de referir a

13 NA, XX, p. 151-152 : "É da nossa natureza moral que decorre o prazer pelo qual os afetos dolorosos nos arrebatam quando os comunicamos".

14 Nesse caso, o estudo mais preciso de "diferentes formas do comovente"; NA XX, p. 156: "Essa espécie de comovente é ainda ultrapassada por aquela na qual a causa da infelicidade não apenas contradiz a moralidade, mas só é possível por meio dela" - da qual o exemplo escolhido são então o personagens de Rodrigo e Ximena no Cid: "Ambos ganham nosso mais elevado respeito (...) ambos inflamam nossa compaixão ao ponto mais elevado, pois eles sofrem voluntariamente e por um motivo que os torna, em um grau mais elevado, dignos de respeito". (É possível ao mesmo tempo surpreender-se com essa escolha, uma vez que o conteúdo "moral" do herói consiste em um "senso da honra" que pode parecer em conflito com a consideração moral universal da humanidade... ). A presença implícita de Kant é bem perceptível na maneira pela qual Schiller conecta nesse caso o "respeito" à expressão "de uma dignidade na felicidade". De maneira clássica, nesse momento, Schiller procura a maneira de colocar em cena um personagem digno de piedade para que ele suscite o máximo de prazer na emoção e evoque (exemplos literários como prova) as diferentes combinações da infelicidade e da virtude nos personagens principais, como o fazem de maneira recorrente os teóricos do trágico precedentes, tanto Lessing quanto Aristóteles, Mendelssohn e Nicolai, quanto àquilo que nos concerne.

15 Ibid., p. 149: é dele que se deve "encontrar [o] fundamento", "na disposição primitiva da alma humana, e poder explicá-lo por meio de uma lei psicológica geral". 
teoria kantiana do sublime à teoria do afeto compassivo. Entretanto, no primeiro momento do texto, ainda centrado no afeto em si mesmo, a base da moralidade, mesmo remetida ao motivo já kantiano da "relação da [nossa] natureza moral e da [nossa] natureza sensível" (NA, XX, p. 150), é, na verdade, centrada na compaixão considerada em sua estrutura de participação simpática; o esquema da educação moral é efetivamente kantiano (enquanto consiste no educar-se a fazer prevalecer a "obediência a leis gerais da razão" sobre a "pulsão egoísta ligada à natureza sensível"), mas ele desemboca também de fato no acesso a outra disposição moral, distinta daquele que prevalece durante a própria educação - precisamente aquela que nos torna "capazes de gozar do prazer da compaixão" (Ibid., grifo nosso).

Por fim, além disso, as últimas linhas desse mesmo parágrafo do ensaio Sobre a arte trágica me detiveram pela fórmula reflexiva que Schiller dá a elas - uma vez que sua demonstração em si mesma poderia certamente se abster de tal recurso à "reflexividade":

Estas [falamos ainda das "almas fortes", igualmente dispostas à compaixão] que são as únicas capazes de se separar delas mesmos, são as únicas a gozar da prerrogativa de tomar parte deles mesmos e a sentir seu próprio sofrimento pelo doce reflexo da simpatia (milden Widerschein der Sympathie).(Ibid., p. 151)

Fica claro, portanto, que se trata em Schiller de um afeto que se moraliza; essa moralização corresponde por um lado à perda do egoísmo primeiramente próprio ao "afeto originário" - 
mas, por outro lado, ela repercute assim igualmente sobre a relação a si: só participa então verdadeiramente de si aquele que está separado de si. Mas o paradoxo é apenas aparente, se se considera que "participar de si" funciona com base no mesmo modelo da "participação" no teatro, ou ainda nas relações intersubjetivas naturais: estamos aí imersos no interior de uma ambiguidade (que seria interessante talvez supor de princípio?) entre o movimento da identificação $e$ o saber subjectivo da dualidade/separação.

No ensaio anterior, encontramos uma indicação ainda mais interessante, uma vez que é acompanhada de uma evocação do sistema por meio do qual Schiller sempre liga emoção e reduplicação participativa do afeto:

Só se pode sentir uma emoção com respeito ao próprio infortúnio quando o sofrimento que ela ocasiona é suficientemente moderado para deixar espaço para o prazer que, por exemplo, o espectador compassivo sente. A perda de um bem de importância nos lança hoje ao chão, e nossa dor toca o espectador; um ano depois nós nos lembramos com emoção desse sofrimento. (NA, XX, p. 138)

É possível aproximar esse processo de participação em si mesmo de um efeito dramático presente no Don Carlos - mesmo que aqui seja a alegria, ou ao menos sua antecipação, que toma o lugar do sofrimento: prestes, ou ao menos é isso que ele crê, a se reconciliar com seu pai, Carlos faz de si mesmo seu próprio recitador - desdobrando-se através de dois procedimentos, por um lado, pela autodescrição de seu sentimento, poetizada 
e imagética, por outro, recorrendo à ficção de uma "assistência" - completamente ideal - para representar a "participação em si mesmo" em que se resolve o modo da emoção que o enlaça:

Um raio de esperança se eleva em mim, como um sol, e um doce pressentimento flutua através de meu coração... O céu inteiro, com seus enxames de anjos felizes, se inclina e desce em nossa direção, e o três vezes Santo contempla, completamente comovido (voll Rührung), essa grande e bela cena... (Don Carlos, II, 2, Versos 1060-1065)

Isso para ilustrar que, quanto à subjetividade, ela por fim consiste, primitivamente, em um círculo - ou melhor, uma elipse com dois focos cuja ação deve necessariamente ser conjunta para engendrar o movimento da subjetividade nela mesma, um movimento que seria sua "auto-afecção", isto é, o afeto reduplicado como emoção: neste circuito "elíptico, o primeiro foco é o eu, e o segundo foco é o outro - tudo se passando como se o primeiro devesse espelhar-se no outro para poder espelhar-se em si mesmo.

\section{O amor para além da compaixão?}

Vocês compreendem então que não estou verdadeiramente convencida da "dedução" que Schiller propõe do "prazer da compaixão", reconduzindo-a ao esquema kantiano do sublime. Não que pudéssemos fazer uma objeção à sua argumentação a partir do interior: mas porque essa dedução, na verdade, não es- 
gota manifestamente outros pontos de partida mais antigos para Schiller no terreno da moral.

Posto isso, resta a questão de saber se para Schiller o choque da descoberta de Kant não poderia ter sido profundo o bastante para reformar realmente motivos morais mais antigos, a partir desse período. Afinal, esse choque foi suficiente para fazê-lo se distanciar do teatro durante vários anos, em favor da filosofia. No entanto, Schiller acabou por fechar sua "butique filosófica" como ele mesmo disse: entretanto, será que ele se tornou efetivamente um tragediógrafo do sublime kantiano no segundo período de sua criação? Será que verdadeiramente escreveu suas últimas peças em real concordância com a dimensão "kantiana" dada à teoria da tragédia em 1791? Ou, antes, deve-se considerar que a sua concepção moral mais antiga e mais profunda teria finalmente "atravessado" seu momento kantiano para manter-se como algo de verdadeiramente próprio?

Vocês não ficarão surpresos de me ouvir defender a segunda hipótese. O tema kantiano, transposto tragicamente, corresponderia à predominância total dada à figura da virtude como sensibilidade heroicamente superada; no Don Carlos, esse tema aparece fugazmente - mas ele é justamente subordinado de maneira clara a todas as outras análises que pudemos desenvolver sobre a compaixão e a emoção, (a saber, este tema aparece no momento em que a rainha censura Posa, o qual morre por Carlos, por ter desejado fazer de sua virtude um "heroísmo" tendo em vista o "sublime" - ... e mesmo se, na verdade, essa morte é ainda por amor). Reconhecer em Schiller o lugar precípuo de um trágico não kantiano deveria, portanto, consistir em acompanhar no seu "segundo período" o devir dramatúrgico do "heroísmo" diante do "amor", o heroísmo tornando-se figura 
verdadeira da virtude. Eu não empreenderei aqui algo assim tão amplo, que envolveria todas as últimas peças; poderíamos nos contentar em assinalar aqui o papel sempre central desse segundo princípio moral - o amor, portanto - em só uma peça deste segundo período.

Em 1788 e anteriormente, Schiller coloca amor e compaixão um em continuidade ao outro. Tivemos a indicação da real destinação do personagem Carlos quando a rainha diz a seu respeito (Don Carlos, I, 5): "o amor, eis seu grande ofício". Aqui vou me dedicar à Noiva de Messina, de 1803 - em primeiro lugar, por conta do prefácio extremamente importante que precede a peça e, em segundo lugar, por conta da inovação formal inédita da presença de um coro (cuja justificação oferece justamente o ensejo ao ensaio de estética geral e teatral do prefácio). Em certo sentido, "tudo mudou de cara": a estética é inteiramente outra, quase que inteiramente depurada, e as influências são agora as da tragédia grega e não mais do drama burguês; por conta da introdução do coro, no plano da forma, o tratamento da participação emotiva dos personagens e dos espectadores tornou-se muito diferente. No plano da matéria, o tema trágico é fornecido pelo ódio, e a influência grega acrescenta a ele o destino: e, no entanto, o valor fundamental, como a dominante ou a terça de uma peça musical escrita em uma modalidade diferente, continua sendo o amor - afirmação que se torna ainda mais poderosa uma vez que ela só se dá negativamente, em relação ao seu contrário: a peça deve o que tem de trágico ao fracasso do amor, o fracasso de uma metamorfose do ódio transformado em amor; este se encontra, aliás, centrado de novo em suas formas pessoais (filial, materno, fraternal, amor de noivos que destinam a partir de então suas vidas ao outro), longe do político; 
mesmo em seu fracasso, o sentimento de amor dá à peça, de um esboço no entanto implacável, um profundo lirismo, e nesse lirismo uma doçura, os quais bastam para mostrar em que sentido a peça, apesar de seu numerosos empréstimos deliberados, não tem nada de verdadeiramente grego - e que não era portanto o projeto de Schiller recolocar anacronicamente um tal modelo na cena moderna.

Nesse drama quase abstrato, como também lírico, o amor não encontra de fato obstáculos a não ser de si mesmo, uma vez que é por amar suas noivas que os irmãos encontram o recurso para superar seu ódio - antes que a identidade dessas duas "noivas", que na verdade é uma só, e aliás não é senão a irmã, faça despedaçar-se o amor com o amor, a fraternidade reencontrada com a esperança do amor conjugal partilhado. Sem dúvida, em nenhuma peça de Schiller a individualidade parece assim se apagar tanto diante da própria potência dos princípios, mas esses mesmos princípios que são aqueles da subjetividade, de modo que quase poderíamos dizer que o amor é o único personagem da peça, ele mesmo se distribuindo em diferentes papéis, enfrentando então a si mesmo a partir daí.

Mas o amor parece precisamente muito mais desligado da compaixão, ao contrário do nó na peça anterior. Notadamente, os coros comentam muito mais do que se compadecem. Então, por que teremos aqui essa dissociação entre o peso devolvido ao amor, que permanece princípio, e a estrutura da compaixão? Seria possível invocar a seguinte análise.

O amor professado por Posa e Carlos era certamente disposição geral à participação; mas se há algo de originário nessa tendência à participação (ao lado da "pulsão egoísta"), devemos ao mesmo tempo levar em conta a necessidade para o sujeito 
de evitar uma armadilha nessa construção de si através da especularidade que tentamos destacar mais acima: essa armadilha estaria na passagem da participação à imagem. O que isso significa? Se o outro é a minha imagem, então de fato não posso mais construir-me nele, pois não se faz outra coisa aí senão representar-me nele. A especularidade realmente intersubjetiva de dois focos alterar-se-ia então em uma especularidade narcisista, rebaixada doravante a um único foco: "a "participação" simpática na dor de outro, nesse sentido, pode muito bem ver sua própria possibilidade fundada sobre uma "co-originaridade" dos sujeitos, mas também resolver-se numa câmara de eco para o sujeito, que apenas permanece como "espectador"; essa compaixão não é amor, pois a disposição originária à participação intersubjetiva se encontra nesse caso por assim dizer "reduzida" pela "pulsão egoísta". Para elevar-se à compaixão, Carlos devia afastar a paixão amorosa, ela mesma governada pela "pulsão egoísta", mas é, portanto, contra o mesmo obstáculo que a compaixão pode ter que lutar novamente por sua vez.

E diante desse destino "abortado" da disposição originária à participação intersubjetiva, compreende-se que, com efeito, para tornar-se moral, esta tem de cumprir todo o caminho que torna a pulsão egoísta "apta" a reconduzir realmente ao outro o eco participativo. Quanto a isso, mais uma vez, Kant pode tomar seu lugar em Schiller: a educação moral pela razão poderá parecer necessária para essa educação do afeto. Aqui, portanto, a concepção kantiana da moralidade é sem dúvida utilizada como meio (causa eficiente do momento da educação moral), mas ela continua efetivamente ainda pouco presente tanto na origem moral como no fim moral. ${ }^{16}$

${ }^{16}$ Nós nos referimos aqui à passagem já citada acima, p. 113 do ensaio 
Na Noiva de Messina, a completa renovação do dispositivo dramático através da introdução dos coros já seria o bastante por si só para sustentar a hipótese de que Schiller exigirá do espectador uma modificação de sua relação participativa com os afetos dos quais ele se faz espectador: a introdução desse "corpo intermediário" não seria um elemento de distanciamento cênico? No prefácio acrescentado à adaptação cênica da Noiva de Messina em uma versão enriquecida com música e novos $\operatorname{coros}^{17}$, o escritor Karl Mickel testemunha, aliás, a cerrada reflexão de Bertold Brecht junto aos escritos teóricos de Schiller quando ele constrói sua concepção de "distanciamento" teatral ${ }^{18}$. Teria Brecht particularmente refletido sobre a frase do ensaio Sobre o uso do coro... no qual Schiller evoca a reintrodução do próprio coro como "parede viva" destinada a "declarar, aberta e sinceramente, a guerra ao naturalismo na arte" (NA, XX, p. 11)? Eu não encontrei evidências diretas que atestem uma leitura precisa deste texto por parte de Brecht (o uso do coro pelo próprio Brecht em $A$ mãe poderia constituir eventualmente um indício disso $\left.{ }^{19}\right)$. Nós devemos, de qualquer maneira, refletir melhor como é que essa "parede" schilleriana faz eco à de Diderot. A "quarta parede" é isso com que gostariam doravante de rom-

Sobre a arte trágica: mesmo se a compaixão seja aí não o ponto de partida, mas o ponto de chegada da educação moral do afeto.

17 Criação o teatro do Freie Volksbühne, em Berlim, em 1990.

18 O próprio Brecht, aliás, cita uma carta de Schiller: cf. Brecht, Écrits sur le théâtre, II, Éd. J. Tailleur, E. Winkler, Paris : L'Arche, p. 522. Cf. JLuc Michel, La Distanciation: essai sur la société médiatique. L'Harmattan, 1992, p. 120 - carta de Schiller a Goethe ; citada a partir de J-F. Chiantaretto, Brecht, penseur intervenant. Paris : Publisud, 1985, p. 60.

19 Die Mutter, 1931. Nessa peça, a personagem brechtiana da mãe tem por nome Pelagea Wlassowa, daí o título de Karl Mickel, mencionado na nota anterior, que não hesita em operar uma aproximação explícita. 
per as estéticas teatrais antinaturalistas ${ }^{20}$ - pois a passagem de uma dessas três etapas à outra (Diderot - Schiller - Brecht) não é isenta de ambiguidade. Diderot aconselhava "imaginar" essa "grande parede", "na borda do teatro", para "separar [os espectadores] da plateia", de modo que os atores atuassem "como se a cortina não se levantasse" (Diderot, 2005, p. 79) 21: a estética teatral naturalista apossar-se-á de sua metáfora para fazer dessa "parede" fictícia o que anularia paradoxalmente o hiato real da cena - para que se possa dar livre campo à ilusão teatral máxima, à qual o espectador gostaria de entregar-se, acompanhado portanto de sua identificação aos personagens; em Brecht, tratase dessa mesma parede. Ora, a "parede" schilleriana é, porém, de uma natureza diferente: certamente, trata-se explicitamente de um anti-"naturalismo", mas através deste Schiller visa sobretudo uma cesura ou, ao menos, um ultrapassamento do real em direção ao ideal - ao passo que Brecht assume o não-naturalismo teatral diretamente no projeto geral de um "realismo". Através da "parede viva" do coro, escreve Schiller, trata-se de "cortar-se completamente do mundo real", maneira pela qual a tragédia "garante seu solo ideal" (NA, XX, p. 11). Ora, o que representa para Schiller "o ideal"? Sem evocar ainda a expressão do ideal do homem que será desenvolvida nas Cartas sobre a educação estética, de 1795, nós evocamos acima o ideal moral em direção

\footnotetext{
${ }^{20}$ Cf. Brecht, «L'achat du cuivre », textes écrits pour la $3^{\mathrm{e}}$ nuit, in : Écrits sur le théâtre, Pléiade, p. 613-614 (menção explícita à "quarta parede"). É o "filósofo" quem enuncia nesse diálogo: "Nós queremos demolir a quarta parede". O "dramaturgo", que se contenta em expor aquilo de que se trata com essa parede fictícia ("atuar com a quarta parede significa portanto atuar como se não houvesse público"), não assume uma posição de modo explícito aqui.
}

21 Diderot, Discurso sobre a poesia dramática, 1758; capítulo 11, "Do interesse". Lessing traduziu esse texto para o alemão em 1760 . 
ao qual "o afeto originário" devia depurar-se, para reencontrar, partindo conjuntamente do egoísmo e do círculo intersubjetivo da participação, o "amor"; o fim do prefácio se apoia sobre essa primeira expressão do ideal, aquele da depuração afetiva, do qual se trata no problema da compaixão: "A alma do espectador deve também preservar sua liberdade mesmo na paixão (Passion) mais violenta, não deve ser presa das impressões, mas se separar sempre clara e alegremente das emoções (Rührungen) que sofre" (NA, XX, p. 14) - e é assim, justamente quanto a isso, que se justifica a introdução do coro como meio de distanciamento afetivo: "O que o juízo comum costuma culpar no coro, a saber, que ele faz cessar a ilusão, que ele interrompe o poder dos afetos, é o que o torna altamente recomendável (...)" (Ibid.). Nestes textos, Schiller já não se esquecia de assinalar na passagem que na compaixão se encontra um momento "reflexivo" - que ele reconhecia mesmo (mas então de modo subordinado) como um dos fatores implicados no prazer próprio à emoção: o "olhar para trás" do "espectador compassivo, sobre si mesmo" (NA, XX, p. 152); esse retorno reflexivo sobre si que marca portanto no próprio processo emotivo da compaixão a possibilidade de um primeiro distanciamento em relação ao afeto do qual se trata ao mesmo tempo de participar; esse "olhar para trás" é agora, ao mesmo tempo, fundamentalmente distinto da "reduplicação" afetiva analisada na estrutura emotiva - reduplicação que, com efeito, continuava imediata a ele e não "posta" pelo próprio sujeito (que se contenta com o círculo "intersubjetivo" no qual ele se deixa "apanhar" pois é antes de tudo nesse círculo que ele se reconhece).

No texto de 1803, é novamente em termos de passividade e de atividade que o papel do distanciamento à emoção é evocado: 
sem o que "a passividade seria superior à atividade" (NA, XX, p. 14). Continuamos no âmbito da estrutura dupla da própria emoção, mas essa mesma dualidade que os ensaios de 1791 investiam no esquema kantiano da dualidade razão/sensibilidade, Schiller a integra aqui, a partir de então, em uma reflexão puramente interna ao circuito teatral do afeto, em um modo próprio de empregar um distanciamento adequado. Gostaria de dizer que, em 1803, tendo chegado de certa maneira à sua maturidade teatral, Schiller não precisa mais de Kant: uma solução propriamente teatral parece ter sido encontrada para o problema moral, que implica doravante a emoção (pelo lirismo) e seu distanciamento formal (aliás, seria assim tão diferente em Brecht, quanto ao resultado, mesmo se as vias são outras?). Essa solução propriamente teatral seria então também a prova de que o afeto pode "depurar-se dele mesmo" para evitar tanto sua "narcisição" como sua recepção sob o modo puramente passivo da "violência".

Nesse sentido, o distanciamento invocado por Schiller é por fim, antes de qualquer coisa, distanciamento moral do sujeito em relação a si mesmo: aquilo é, na verdade, o em vista do que, com efeito, é convocado o distanciamento da cena em relação ao espectador; mas esse distanciamento moral de si mesmo, que em 1791 adotara a forma da teoria do sublime, baseada sobre o hiato da razão e da sensibilidade, encontra finalmente uma forma nela mesma mais schilleriana, uma vez que o hiato aqui dá lugar à figura da oscilação: para Schiller (bem como para Fichte), trata-se para o sujeito de "flutuar" entre atividade e passividade, segundo as próprias condições originárias de seu ser condições originárias às quais se deve de certa maneira "elevar-se novamente"(Ibid.) para visar o ideal. Assim, não devemos, diz Schiller quanto ao equilíbrio da atividade e da passividade, ces- 
sar de "flutuar" "por sobre a matéria" (do afeto), porque a forma na qual ele nos é dado pode já nos "restituir nossa liberdade". Seria aqui o caso, sem dúvida, de falar antes de um Schiller, quanto a isso, mais fichtiano que kantiano.

\section{Referências bibliográficas}

BRECHT, B. Écrits sur le théâtre, Paris: Gallimard/Pléiade, 2000.

CHIANTARETTO, J.-F. Brecht, penseur intervenant. Paris: Publisud, 1985.

COHN, D. "Un oubli de Kant", in: L'Artiste, le vrai, le juste. Paris: Éditions rue d'Ulm/Musée du quai Branly, 2014, pp. 37-54.

LESSING, G. E. Briefwechsel über das Trauerspiel [1756/57], hg. v. Jochen Schulte-Sasse, München 1972.

MICHEL, J.-L. La Distanciation: essai sur la société médiatique. Paris: L'Harmattan, 1992

SCHILLER, F. Schillers Werke. National-Ausgabe Bd. 20: Philosophische Schriften. Erster Teil. Unter Mitw. von Helmut Koopmann hrsg. von Benno von Wiese. Weimar: Böhlaus, 1962. Unveränderter Nachdr. 2001. Weimar: Böhlaus. Bd XX.

. Don Carlos, Paris: Aubier Montagne,1978. 
